\title{
O Teatro do Oprimido em processos de criação, ensino e aprendizagem com mulheres
}

\section{Resumo}

Esta pesquisa tem por objetivo investigar a metodologia do Teatro do Oprimido (TO) em processos de criação, ensino e aprendizagem com mulheres em situação de opressão. Desenvolve-se um exercício analítico, interpretativo e reflexivo sobre a experiência com o Grupo de Teatro das Oprimidas Mulheres no Espelho (GTO-ME) da Organização Não Governamental (ONG) Casa Sr Tito, localizada no bairro Palmital, em Lagoa Santa (MG). Através de procedimentos do Teatro Imagem, uma das técnicas do TO, desenvolveram-se experiências pessoais e coletivas, numa tentativa de ler o pensamento e as emoções do grupo, como também de mapear situações de opressão, refletindo sobre o mundo ao nosso redor, como ele nos toca e nos afeta e, consequentemente, como afetamos o mundo. Adota-se como referencial teórico a metodologia do TO, desenvolvida por Augusto Boal (2002; 2005; 2009; 2013; 2015), como também estudos práticos e teóricos empreendidos por curingas tais como, Flávio Sanctum (2016), Bárbara Santos (2010), Claudete Félix de Souza (2017). A geração de dados e registro dos rastros do processo se deu através de diário de itinerância, registro audiovisual, coleta de relatos das participantes, planos de curso e de aula. Adotou-se a Pesquisa-ação (BARBIER, 2007) como metodologia de pesquisa.

Palavras-chave: Pedagogia do teatro. Teatro do oprimido. Relações de gênero.

\section{Abstract}

This research aims to investigate the methodology of the Theater of the Oppressed (OT) in the processes of creation, teaching and learning with women in situations of oppression. An analytical, interpretive and reflective exercise was developed on the experience with the Group of Theater of the Oppressed Women in the Mirror (GTOME) from the Non-Governmental Organization (NGO) Casa Sr Tito, located in Palmital neighborhood, Lagoa Santa (MG). Through the procedures of the Image Theater, one of the OT techniques, personal and collective experiences were developed in an attempt to read the group's thoughts and emotions, as well as to map situations of oppression, reflecting on the world around us as it touches and affects us and, consequently, how we 
affect the world. The theoretical methodology used by Augusto Boal (2002, 2005, 2009, 2013, 2015), as well as theoretical and practical studies undertaken by jokers such as Flávio Sanctum (2016), Bárbara Santos (2010, Claudete Félix de Souza (2017) were adopted. The data generation and recording of the traces of the process took place through a itinerance diary, audiovisual record, collection of reports from participants, course plans and lessons. The action research (BARBIER, 2007) was adopted as a research methodology.

Keywords: Theater pedagogy. Theater of the oppressed. Gender relations.

Esta pesquisa é oriunda do mestrado em andamento e tem por objetivo investigar a metodologia do Teatro do Oprimido (TO) em processos de criação e de ensino e aprendizagem com mulheres em situação de opressão. Desenvolve-se um exercício analítico, interpretativo e reflexivo sobre a experiência com o Grupo de Teatro das Oprimidas Mulheres no Espelho ${ }^{1}$ (GTO-ME) da Organização Não Governamental (ONG) Casa Sr Tito, localizada no bairro Palmital, em Lagoa Santa (MG).

Adota-se como referencial teórico a metodologia do TO, desenvolvida por Augusto Boal $(2002 ; 2009 ; 2013 ; 2015)$, como também estudos práticos e teóricos empreendidos por curingas $^{2}$ tais como, Flávio Sanctum (2016), Bárbara Santos (2010), Claudete Félix de Souza (2017). Para geração de dados e registro dos rastros do processo, alguns recursos foram utilizados: diário de itinerância, registro audiovisual, coleta de relatos das participantes, planos de aula. Identificam-se, através da prática, questões que a ela se impõem.

Adotou-se a Pesquisa-ação (BARBIER, 2007) como metodologia de pesquisa. Esta se constrói a partir da prática do pesquisador, que se apresenta como sujeito, objeto e investigador durante o trabalho. Explanando sobre a Pesquisa-ação integral, Barbier (2007, p. 77) aborda aspectos que em muito dialogam com as bases do TO. Na

\footnotetext{
${ }^{1}$ Entre agosto de 2017 e março de 2018, realizamos 11 encontros do GTO-ME, com um público flutuante de 21 mulheres.

${ }^{2}$ Curinga é o nome dado ao mestre de cerimônias, ao mediador do espetáculo fórum e também ao agente comunitário, multiplicador do Teatro do Oprimido. São artistas com função pedagógica, praticantes, estudiosos e pesquisadores do TO. É o Curinga quem orienta o processo criativo e pedagógico do grupo, buscando uma forma mais democrática de diálogo.
} 
Pesquisa-ação, os atores, independente de suas condições sociais, devem poder "planejar, organizar e realizar eles mesmos suas mudanças de um modo consciente, livre e inteligente com o máximo possível de reflexão" (idem), tal qual o TO que, traz em si, a potencialidade de tornar os espectadores, protagonistas. Sua poética propõe a própria ação. $\mathrm{O}$ espectador não delega poderes ao personagem para que atue nem para que pense em seu lugar. Pelo contrário, o espectador transforma a ação dramática, ensaiando soluções possíveis.

A escolha por estas metodologias se relaciona, dentre outros aspectos, ao fato de almejar-se a realização de mudanças, reverberações, a partir dos encontros com o GTOME e da experiência estética teatral. Boal (2005, p. 19) enfatiza que o TO busca sempre a transformação da sociedade no sentido da libertação dos oprimidos. A trajetória do GTO-ME, iniciado em 2016, tem comprovado sua potencialidade em provocar mudanças, seja no que se refere à autoimagem dos sujeitos ou à forma de colocar-se politicamente em sociedade, seja na atuação em prol em mudanças legislativas - o coletivo elaborou uma ação legislativa indo até à Câmara dos Vereadores da cidade para se fazer presente frente à reivindicações na área da saúde que criava regras infundadas para o uso do SUS. Portanto, nesta pesquisa reflete-se como o TO pode contribuir para a formação estética, política e social das mulheres participantes e para a comunidade na qual estão inseridas.

Nos encontros do GTO-ME, experimentamos alguns procedimentos do Teatro Imagem, uma das técnicas do TO. Boal $(2015$, p. 47) enuncia que "o Teatro Imagem é uma ferramenta essencial para envolver o espectador, estimulando a sua criatividade". Esta técnica baseia-se "no reflexo múltiplo do olhar do outro" (Ibid., p. 216). O Teatro Imagem tende a desenvolver a linguagem visual, prescindindo da palavra.

A escolha por esta técnica teatral deve-se a sua potência em suscitar representações, leituras e reflexões que colocam os corpos dos sujeitos em ação. Saindo do campo estritamente verbal, as abordagens imagéticas logram multiplicar perspectivas. Desta forma, nos encontros com o GTO-ME nos detivemos sobre as experiências pessoais e coletivas das mulheres, numa tentativa de ler o pensamento e as emoções do grupo, como também de mapear situações de opressão. Refletindo sobre o mundo ao nosso redor, como ele nos toca e nos afeta e, consequentemente, como afetamos o mundo. 


\section{REFERÊNCIAS}

BARBIER, René. A pesquisa-ação. Tradução: Lucie Didio. Série Pesquisa. Vol.3. Brasília: Liber Livro Editora, 2007.

BOAL, Augusto. Teatro do Oprimido e outras poéticas políticas. Rio de Janeiro: Civilização Brasileira. 2005.

Jogos para atores e não atores. São Paulo: Cosac Naify, 2015. 